Section Editor

Mitchell S.V. Elkind,

MD, MS

\title{
Teaching Video NeuroImages: Spinal and bulbar muscular atrophy mimicking essential tremor
}

\section{回}

Antonios Kerasnoudis, MD

Gisa Ellrichmann, MD

Ralf Gold, MD

Carsten Saft, MD

Correspondence \& reprint requests to Dr. Kerasnoudis: antonis.kerasnoudis@gmail.com
Supplemental data at www.neurology.org
A 43-year-old man presented with 5 years of an alcohol-sensitive postural tremor, diagnosed as essential tremor. Family history was positive for tremor on his paternal side and for muscular weakness in his maternal grandfather. Examination revealed gynecomastia, a medium to high frequency weight bearing sensitive postural tremor, a proximal atrophic tetraparesis (video on the Neurology ${ }^{\circledR}$ Web site at www. neurology.org), fasciculations, and tongue weakness. Molecular testing confirmed the diagnosis of spinal bulbar muscular atrophy (38 CAG repeats). Postural tremor associated with gynecomastia should raise concern for spinal bulbar muscular atrophy. ${ }^{1,2}$

\section{AUTHOR CONTRIBUTIONS}

Dr. Kerasnoudis acquired, analyzed, and drafted the content of this video/ case report including medical writing. Dr. Ellrichmann contributed to the acquisition of the video of this video/case report. Dr. Gold revised the manuscript for content and did the supervision of this video/case report. Dr. Saft contributed to the acquisition of the video and analyzed and revised the content of this video/case report.

\section{REFERENCES}

1. Atsuta N, Watanabe H, Ito M, et al. Natural history of spinal and bulbar muscular atrophy (SBMA): a study of 223 Japanese patients. Brain 2006;129:14461455 .

2. Hanajima R, Terao Y, Nakatani-Enomoto S, et al. Postural tremor in $\mathrm{X}$-linked spinal and bulbar muscular atrophy. Mov Disord 2009;24:2063-2069. 


\section{Neurology}

\section{Teaching Video NeuroImages: Spinal and bulbar muscular atrophy mimicking essential tremor}

Antonios Kerasnoudis, Gisa Ellrichmann, Ralf Gold, et al. Neurology 2012;78; 41

DOI 10.1212/WNL.0b013e318245d2bd

\section{This information is current as of February 6, 2012}

\section{Updated Information \&} Services

Supplementary Material

\section{References}

Subspecialty Collections

Permissions \& Licensing

Reprints including high resolution figures, can be found at: http://n.neurology.org/content/78/6/e41.full

Supplementary material can be found at: http://n.neurology.org/content/suppl/2012/02/05/78.6.e41.DC1

This article cites 2 articles, 0 of which you can access for free at: http://n.neurology.org/content/78/6/e41.full\#ref-list-1

This article, along with others on similar topics, appears in the following collection(s):

All Movement Disorders

http://n.neurology.org/cgi/collection/all_movement_disorders

Endocrine

http://n.neurology.org/cgi/collection/endocrine

Motor Control

http://n.neurology.org/cgi/collection/motor_control

Muscle disease

http://n.neurology.org/cgi/collection/muscle_disease

Information about reproducing this article in parts (figures,tables) or in its entirety can be found online at:

http://www.neurology.org/about/about_the_journal\#permissions

Information about ordering reprints can be found online:

http://n.neurology.org/subscribers/advertise

Neurology ${ }^{\circledR}$ is the official journal of the American Academy of Neurology. Published continuously since 1951 , it is now a weekly with 48 issues per year. Copyright Copyright $@ 2012$ by AAN Enterprises, Inc.. All rights reserved. Print ISSN: 0028-3878. Online ISSN: 1526-632X.

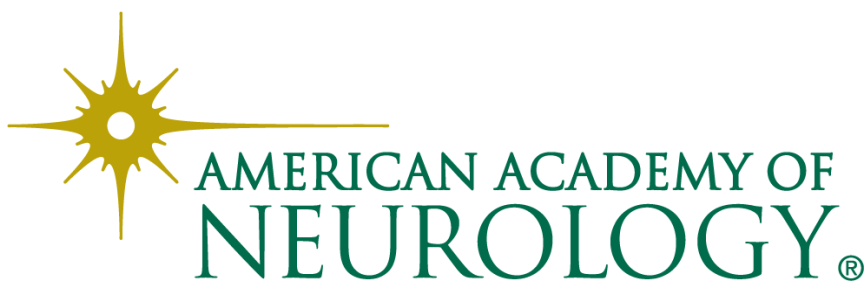

